\title{
Japanske interaktive partikler i dansk oversættelse
}

Obe, Rie; Haberland, Hartmut

Published in:

NyS

DOI:

10.7146/nys.v1i57.117120

Publication date:

2019

Document Version

Peer-review version

Citation for published version (APA):

Obe, R., \& Haberland, H. (2019). Japanske interaktive partikler i dansk oversættelse. NyS, (57), $113-138$.

https://doi.org/10.7146/nys.v1i57.117120

\section{General rights}

Copyright and moral rights for the publications made accessible in the public portal are retained by the authors and/or other copyright owners and it is a condition of accessing publications that users recognise and abide by the legal requirements associated with these rights.

- Users may download and print one copy of any publication from the public portal for the purpose of private study or research.

- You may not further distribute the material or use it for any profit-making activity or commercial gain.

- You may freely distribute the URL identifying the publication in the public portal.

Take down policy

If you believe that this document breaches copyright please contact rucforsk@kb.dk providing details, and we will remove access to the work immediately and investigate your claim. 


\title{
Japanske interaktive partikler i dansk oversattelse
}

\author{
RIE OBE OG HARTMUT HABERLAND
}

En række småord i moderne germanske V2-sprog har visse træk til fælles med sætningsslutpartiklerne i asiatiske sprog. Det er dog ikke klart hvor langt de ligner hinanden. Vi ser her på danske dialogpartikler og japanske interaktionspartikler ved at sammenligne uddrag af en roman af Haruki Murakami med deres oversættelse til dansk. Selv om disse partikler inden for deres respektive sprogs typologiske ramme har overraskende mange træk til fælles som leksikalske enheder, er deres tekstforekomster sjældent direkte oversættelser af hinanden. Danske dialogpartikler forudsætter en (ofte implicit) samtale, dvs. tilstedeværelse af mere end én stemme (det som også bliver kaldt for polyfoni), mens de japanske interaktionspartikler organiserer interaktionspartnernes indbyrdes engagement (og forudsætter i højere grad en modpart der er fysisk til stede eller i det mindste præcist socialt defineret).

Nøgleord: dialogpartikler, interaktionspartikler, dansk, japansk

\section{FRAGESTELLUNG}

I flere af verdens sprog findes der en gruppe af småord, der i lighed med den større gruppe af diskursmarkører er korte, ikke-referentielle, interpersonelle og interaktive, men derudover er partikler: De er på én, højst to stavelser (eller morae), kan ikke få tryk, kan ikke udgøre en selvstændig ytring, kan ikke være et fuldstændigt svar på et spørgsmål og har skopus på hele ytringen og ikke en enkelt konstituent (Arndt 1960: 326).

Blandt de europæiske sprog har alle moderne germanske V2-sprog partikler af denne art. Forholdene for islandsk er specielle og behøver ikke at beskæftige os, men det er velkendt at partikler af denne art ikke findes i engelsk (Schubiger 1965). Tilsvarende partikler findes til gengæld i russisk (Arndt 1960). Desuden findes tilsvarende partikler i sydøstasiatiske sprog som kinesisk pŭtōnghuà (standardmandarin) (Simpson 2014), kantonesisk (Luke 1990), koreansk (Pak 2008), vietnamesisk (Ha \& Grice 2017) og thai (Cooke 1989).

Terminologien varierer betydeligt. Mens man for de europæiske sprog har brugt bl.a. 'modalpartikler' og Abtönungspartikel, taler man for dansks vedkommende siden den grundige beskrivelse i Hansen og Heltoft (2011) mest om 'dialogiske partikler', et begreb der ikke bliver brugt, men antydet hos Torben Andersen (1982). For de asiatiske sprog har man mest hæftet sig ved deres sædvanlige position i slutningen af en helsætning og talt om 'sætningsfinale partikler'. På japansk kunne de dog tidligere også stå andre steder i en sætning; mange af dem (især ne og sa) kan stadigvæk i dag stå i slutningen af et syntagme (Lewin 1959: 103, Bloch 1946: 202).

Ifølge Obe \& Haberland (2018: 119-120) er det forbløffende, hvor mange af de ovenfor nævnte egenskaber for 'småord' de danske dialogiske partikler deler med i hvert fald en undergruppe af de japanske sætningsfinale partikler. Det er intuitivt tydeligt både for japansktalende, der lærer dansk, 
og dansktalende, der lærer japansk, at partiklerne i de to sprog ligner hinanden, men at de alligevel er forskellige på en eller anden måde. Spørgsmålet er så, på hvilken måde de afviger fra hinanden.

Dette ser vi nærmere på i det følgende. Vi gør os overvejelser over først vores metode, nemlig at bruge oversættelser til at sammenligne de danske dialogiske partikler og de japanske partikler, og vi gennemgår derefter, både hvordan de danske dialogiske partikler defineres hos Hansen \& Heltoft (2011), og hvordan de japanske interaktive partikler defineres hos Ogi (2017) (hvor de interaktive partikler udgør en undergruppe af de japanske sætningsfinale partikler). På denne baggrund præsenterer vi vores analyse af eksemplerne, først eksempler i dialog, så eksempler uden for dialog og til sidst eksempler i fortællertekst.

\section{OVERSÆTTELSER}

Der er en tradition for at angribe forholdet mellem partikler i forskellige sprog som en slags oversættelsesproblem, fx hos Baunebjerg og Wesemann (1983) for dansk og tysk, og hos Wienold (2004) for japansk og tysk. Som oversættelsesproblem ser spørgsmålet således ud: hvis en dansk partikel, fx jo, optræder i en sætning i en tekst, hvordan skal partiklen så oversættes til japansk? Så kan man måske - som Baunebjerg og Wesemann (1983) i et os bekendt aldrig afsluttet projekt foreslog - skrive en Partikelwörterbuch for de pågældende sprog. Vores undersøgelse sår dog tvivl ved denne procedure, da oversættere sjældent bare oversætter enkelte ord og føjer dem sammen. At enkeltord kun kan indgå i en oversættelse, ikke oversættes isoleret, gælder i høj grad netop partikler. ${ }^{1}$

Et eksempel på en dansk dialogisk partikel i et eventyr af H. C. Andersen er: ${ }^{2}$

(1) »Ja jeg er jo istand!« sagde Keiseren. (Dal 1963: 110)

I to japanske oversættelser lyder dette således:

(1') sōka, washi mo shitaku ga deki-ta zo. (Ōhata 2016: 163) ${ }^{3}$

UDR jeg FOK forberedelse SUBJ færdiggøre-DAT PART

$\left(1^{\prime \prime}\right)$ wakat-ta, washi dat-tara yōi ga deki-teiru zo. (Fukui 1988: 125) forstå-DAT jeg KOP-KOND forberedelse SUBJ færdiggøre-PROG PART

Da den danske sætning indeholder en partikel, og de to japanske oversættelser også indeholder hver en partikel, kunne man forledes til at mene, at den japanske partikel zo var en oversættelse af den

\footnotetext{
${ }^{1}$ Aijmer et al. (2006) diskuterer hvordan man kan sammenligne pragmatiske markører generelt mellem sprog gennem oversættelseskorpora. Deres eneste eksempel er dog den engelske diskursmarkør well (ikke en partikel i vores forstand), som bliver sammenlignet med svensk $j a$.

${ }^{2}$ H. C. Andersen citeres efter Erik Dals udgave (se kildefortegnelsen). Partiklerne er fremhævet med fed.

${ }^{3}$ Ōhata skriver i forordet til sin udgave (2016), at han har oversat efter Andersens Eventyr og Historier $i 5$ bind, udgivet af Hans Brix og Anker Jensen (København: Gyldendal 1943), og at han også har spurgt nogle tyske og engelske oversættelser til råds. I onlineversionen er kildernes japanske tekst opført $\mathrm{i}$ et appendiks. For forkortelser anvendt $\mathrm{i}$ glosseringerne (der følger Leipzigprincipperne) se appendiks.

${ }^{4}$ Ifølge Fukui (1988: i) har hun oversat efter H. C. Andersens eventyr i udvalg (København: Forlaget Notabene 1974).
} 
danske partikel jo. Hvis man ser på funktionerne af hhv. jo og zo, virker det dog ikke umiddelbart sandsynligt. Ifølge beskrivelsen af dansk jo i Hansen \& Heltoft (2011) og japansk zo i Ogi (2017) markerer dansk jo i (1), at den talende (= kejseren) forudsætter, at den modtagende (= overceremoniministeren) ikke vil modsige ham med hensyn til det propositionelle indhold (= kejseren er klar), mens det japanske zo i (1') og (1") markerer en implikatur ved ytringerne, dvs. "Vi kan gå nu foran folket og præsentere os". Således har de to partikler ikke den samme funktion, og den japanske $z o$ kan ikke være en oversættelse af den danske jo. ${ }^{5}$

Når den originale tekst er oversat 'i tandem' med en oversættelse til et 'ikke-partikelsprog' (normalt engelsk) som mellemtrin, burde vi forvente at der ikke optræder partikler i oversættelsen, da der ikke er noget i midtvejsoversættelsen, der kunne oversættes med en partikel til japansk. Hvis mellemsproget er engelsk, burde det fungere som en slags partikelstøvsuger. Men det er ikke nødvendigvis tilfældet; når det lille barn i "Kejserens nye Klæder” siger

(2) »Men han har jo ikke noget paa.«(Dal 1963: 111)

så hedder det i Ōkubo Yūs oversættelse

(2') ō-sama, hadaka da yo. (Ōkubo 1999 on-line)

konge-HøF nøgen KOP.NUT PART

Ōkubo angiver som sin kilde en engelsk oversættelse, ${ }^{6}$ hvor vi finder

$\left(2^{\prime \prime}\right)$ "But he has nothing on at all."

Her kan yo med andre ord ikke være en oversættelse af jo (som den japanske oversætter ikke kunne vide noget om).

Det er oplagt og nærliggende at bruge sammenlignelige korpora og især korpora, der inkluderer interaktion, hvis man vil sammenligne ordinventar, sprogbrug og konstruktioner fra to sprog. Der vil dog normalt mangle et vigtigt grundlag for sammenligningen, da ytringerne $\mathrm{i}$ de to korpora ikke står i noget defineret forhold til hinanden. ${ }^{7} \mathrm{Vi}$ har derfor valgt i stedet for at sammenligne oversættelser af litterære tekster (sml. også Haberland \& Obe 2018). Det har ikke bare den fordel, at sætningerne i oversættelsen i det mindste er ment som direkte gengivelse af sætningerne i originalteksten. Siden de japanske partikler oftest er et typisk talesprogsfænomen, og da også de danske tit (om end ikke udelukkende) optræder i samtale, er det en fordel at litterære tekster ofte indeholder talegengivelse, hvilket er præcist, hvad vi leder efter. Dog findes der ikke så mange japanske litterære tekster, som er oversat til dansk. Blandt de relativt få danske oversættelser har vi valgt at undersøge Mette Holms

\footnotetext{
${ }^{5}$ Vores ærinde i denne artikel er ikke oversættelseskritik. Vi kan ikke forholde os til om oversætteren har truffet det rigtige valg - hvilket vi dog ingen grund har til at anfægte.

${ }^{6}$ Om den lidt rodede kildesituation se Haberland og Obe (2018: 77, fodnote 6).

${ }^{7}$ Hvis det drejer som om leksikalske enheder som verber, er det måske et mindre problem, jf. Slobin (1996); vi undersøger her partikler hvis pragmatiske funktion næppe kan udskilles fra ytringen eller hele teksten.
} 
oversættelse af Murakami Harukis roman Umibe no Kafuka til dansk (Kafka på Stranden, 2007), fordi romanen inkluderer en del dialog og også er velkendt hos danske læsere. ${ }^{8}$

\section{DESKRIPTIVT UDGANGSPUNKT}

Som vores deskriptive udgangspunkt anvender vi for de danske dialogiske partikler Hansen \& Heltoft (2011), og for de japanske såkaldte sætningsfinale partikler Ogi (2017). Hansen og Heltoft siger om de danske dialogiske partikler:

Dialogiske partikler er også altid udtryk for et subjektivt synspunkt - for den talendes synspunkt - men pointen er at der er mindst et synspunkt til, og det bæres af en der ikke er den talende. I en bestemt tradition taler man om polyfoni, en flerhed af synspunkter (ytringer eller 'stemmer'). Sådanne partikler og sætningsadverbialer der også indeholder et objektivt placeret synspunkt, siges at være polyfone, flerstemmige. (2011: 1037)

Danske partikler forudsætter flere stemmer, som afsenderen forholder sig til. Men det behøver ikke at foregå i en dialog mellem to eller flere parter; også afsenderen af en prosatekst kan konstruere et dialogisk univers og indgå i en implicit dialog med læseren (Gray 1977). I litterære tekster vil der ofte findes dialog på mindst to niveauer: dialog mellem tekstens personer og den implicitte dialog mellem forfatter og læser.

Ogi fokuserer i sin beskrivelse på syv af de japanske sætningsfinale partikler, ne, na, yo, sa, wa, ze og zo, og hun kalder dem for interaktive markører ${ }^{9}$ med særligt henblik på deres funktioner, ikke deres topologiske træk. Ifølge Ogi markerer de interaktive partikler samtaledeltagernes engagement ("involvement") i samtalens indhold eller i deltagerne selv og for nogles vedkommende underforståethed ("implied meaning") (Ogi 2017: 33 et passim). Ifølge hende forekommer de japanske interaktive partikler typisk i uformel dialog, og de findes sjældent i skriftsproget. Ogi mener også, at det føles unaturligt at have en samtale uden at bruge disse interaktive partikler på japansk (Ogi 2017: 1-3). På den anden side kan hun vise med et tankeeksperiment (2017: 67-70), at de ikke kan optræde i sagprosa.

For de japanske interaktive partikler findes altså nogle betingelser for, hvilke ytringer de kan bruges $i$, mens der ikke findes lignende indskrænkninger for de danske dialogiske partikler. Derfor forventer vi i vores undersøgelse, at forekomsterne af partikler i de to sprog er forskellige, alt efter hvilke ytringstyper de bruges i: Om de bruges i direkte talegengivelse i dialog, i direkte talegengivelse uden for dialog (herunder tankegengivelse) eller i fortællerteksten i litterær prosa.

De danske partikler, som vi omtaler i det følgende er: altså, jo, $n u, d a$. Hos Hansen \& Heltoft (2011) hører disse fire partikler til forskellige partikeltyper: jo er en fatisk partikel, $d a$ og $n u$ er proksimale partikler og altså er en argumentativ partikel. ${ }^{10}$ Jo kan parafraseres som "Jeg siger $\mathrm{P}$

\footnotetext{
${ }^{8}$ Vores ærinde i denne artikel er ikke oversættelseskritik. Vi kan ikke forholde os til, om oversætteren har truffet det rigtige valg - hvilket vi dog ingen grund har til at anfægte.

9 Den direkte oversættelse af Ogis "interactive markers" er interaktive markører, men i det følgende vil vi tale om interaktive partikler.

10 "De fatiske partikler markerer relationen og forventningerne mellem den talende $\mathrm{T}$ og modtageren $\mathrm{H}$; de proksimale partikler angiver sætningen bestemthed og dermed sagforholdets identificerbarhed [...]; de argumentative partikler angiver at den talende gør sin replik til et argument mod et andet synspunkt [...]" (Hansen \& Heltoft 2011: 1061-1062).
} 
[propositionelt indhold]. Du vil være enig her og ikke modsige mig" (Hansen \& Heltoft 2011: 1050). Derimod forudsætter brugen af $n u$ eller $d a$ "et modsynspunkt som den talende forholder sig til gennem sin ytring" (Hansen \& Heltoft 2011: 1053). Der er dog forskel mellem da og $n u$ : " $n u$ forudsætter at det fremsatte synspunkt - ikke modsynspunktet - indføres i situationen med ytringen [...]. Ved $d a$ kan synspunktet være velkendt for begge samtalens parter" (Hansen \& Heltoft 2011: 1055). Derudover er $d a$ og $n u$ også på et andet punkt forskellige fra jo: mens den talende ved brugen af jo ikke regner med en respons fra den tiltalte, findes der ikke nogen tilsvarende betingelse ved brugen af $d a$ og $n u$ (Hansen \& Heltoft 2011: 1053). Altså har som en dialogisk partikel den følgende betydning: "Den talende mener at ytringen vil være i modstrid med de ønsker eller hensigter modtageren kan formodes at have" (Hansen \& Heltoft 2011: 1079), og derfor fungerer ytringen med

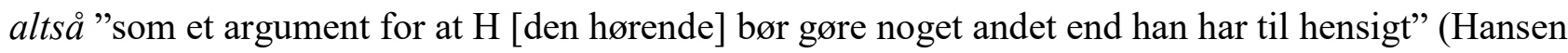
\& Heltoft 2011: 1080).

Ogi deler de syv japanske interaktive partikler i to grupper: (i) "incorporative", ne og na, og (ii) "monopolistic", yo, sa, wa, ze og zo.

$\mathrm{Ne}$ and $n a$ invite the hearer's involvement in an incorporative manner, by which the speaker is committed to align with the hearer with respect to the content and feeling conveyed in the utterance. Further, yo, sa, wa, zo and ze invite the hearer's involvement in a monopolistic manner, by which the speaker is committed to enhance his/her position as a deliverer of the content and feeling conveyed in the utterance. (Ogi 2017: 198)

Det ene vigtige begreb i definitionen er 'monopolistisk'. Taleren inviterer lytterens engagement, men på sine egne betingelser: "Hør nu her, jeg har noget jeg gerne vil fortælle dig!" eller: "Jeg er taleren, og du lytter mens jeg taler til dig." (sml. Ogi 2017: 83). ${ }^{11}$ Blandt de monopolistiske partikler har yo, $z o$ og ze den særlige funktion, at brugen af partiklerne indkoder, at der er en implikatur forbundet med ytringen (Ogi 2017: 130 et passim). Heroverfor står de inkorporative partikler, der tager hensyn til lytterens standpunkt, og som kan parafraseres som "Synes du det ikke også?" (Ogi 2017: 73).

\section{ANALYSE}

I det følgende deler vi forekomsterne op efter tre mulige ytringstyper, i hvilke partiklerne kan optræde i en litterær tekst: i direkte talegengivelse i dialog, i direkte talegengivelse uden for dialog (herunder tankegengivelse) og i fortællerteksten. ${ }^{12}$ Inden for disse grupper ser vi, om der forekommer partikler såvel i den japanske tekst som den danske oversættelse, eller om der er japanske partikler i teksten, som ikke har et modstykke i oversættelsen, og til sidst om der er sætninger uden partikel i originalen, hvor der optræder en partikel i oversættelsen.

\subsection{EKSEMPLER I DIALOG}

\footnotetext{
${ }^{11}$ I CA-analyser af japansk yo (fx Hayano 2011) anvendes udtrykket 'vidensforspring' (epistemic primacy), som er beslægtet med, men ikke identisk med Ogis monopolistiske talerholdning. Den går snarere på "Jeg har bedre forudsætninger for at udtale mig om dette her end dig."

${ }^{12} \mathrm{Vi}$ vil i denne artikel se bort fra indirekte talegengivelse og dækket indirekte tale for ikke at brede os alt for vidt. Ifølge Coulmas (1985) er skelnen mellem direkte og indirekte talegengivelse i forvejen ikke tydelig i japansk; vi er ikke klar over, om dækket indirekte tale (style indirect libre, oratio tecta) overhovedet findes på japansk.
} 
Først ser vi på nogle eksempler, hvor en japansk tekst med mange interaktive partikler oversættes til en dansk tekst uden eller med få dialogiske partikler. Det følgende eksempel er fra prologen af Kafka på stranden, hvor fortælleren, drengen Kafka, taler med sit andet jeg eller sin usynlige ven, Krage. ${ }^{13}$ Konteksten er, at Krage lige før har spurgt Kafka (som er ved at stikke af hjemmefra), om han vil finde et sig job. Dertil svarer Kafka undvigende:

(3) Kafka: "Måske." (...)

Krage: "Du er altså nødt til at finde ud af, hvordan verden er skruet sammen. (...) Du er stadig i den skolepligtige alder. (...)" (...)

Krage: "Nå, fred være med det. (...) Det nytter ikke at forestille sig det værste, før man overhovedet er begyndt. Du har jo besluttet dig. (...) Men fra nu af er du nødt til at blive en rigtig hård negl."

Kafka: "Jeg gør mit bedste." (...)

Krage: "Ja, det tør siges (...) Det har ikke undgået min opmærksomhed, at du er blevet meget stærkere de sidste år. (...) Verden er fuld af ting, som du aldrig har oplevet, som du end ikke kan forestille dig." (...)

Kafka: "Uanset hvad der sker, er jeg nødt til at komme væk herfra. Det kan der ikke laves om på." (...)

Krage: "Det har du nok ret i. (...) Det er ikke for at tage modet fra dig, men lige meget hvor langt væk du tager, kan du ikke være sikker på, du slipper væk. Jeg tror ikke, du skal gøre dig nogen forhåbning om, at afstand gør en forskel." (Holm 2007: 6-7) ${ }^{14}$

I hele denne dialog (som vi gengiver lidt forkortet) optræder der i den japanske original elleve interaktive partikler, mens den danske oversættelse kun indeholder tre dialogiske partikler, herunder kun en enkelt (altså) i en sætning, hvor der optræder en interaktiv partikel i den japanske original:

(4) nee, kimi wa motto seken tte mono o shira-nakuchaikenai yo.

UDR du TOP mere verden CITAT ting OBJ finde.ud.af-være.nødt.til PART

(4') Du er altså nødt til at finde ud af, hvordan verden er skruet sammen.

Yo markerer at den talende opfordrer den hørende til at høre ordentligt efter, muligvis med det underforståede budskab at Kafka skal finde sig et job. Altså skal læses som ”Jeg formoder at du har andre ønsker eller hensigter, men jeg er nødt til at sige det alligevel, fordi jeg synes du skal gøre hvad jeg siger" (sml. Hansen \& Heltoft 2011: 1079).

I (4) og (4') ser yo og altså ud til at have funktioner som ligner hinanden, og sådan et eksempel kan lokke os til at konkludere, at altså er en oversættelse af yo, men vi må også konstatere, at der er eksempler med yo i samme funktion som i (4), hvor der i oversættelsen ikke optræder altså, og at der omvendt er eksempler af oversættelser med altså, hvor der ikke bruges yo i originalen. Derfor må vi

\footnotetext{
${ }^{13}$ Tjekkisk kavka betyder 'krage'.

14 Talerens navn er tilføjet af os.
} 
konkludere, at altså i (4') ikke er en oversættelse af yo i (4) på trods af affiniteten mellem de to partiklers funktioner.

Den japanske original indeholder yderligere ti partikler, som i hvert fald ikke gengives med dialogiske partikler på dansk (tre gange ne, en gang $n a$, ud over eksemplet i (4) yderligere to gange $y o$, en gang $s a$ og tre gange ze). De japanske partikler afspejler dialogpartnernes engagement $\mathrm{i}$ hinanden og i samtalen, og desuden Kafka og Krages tætte forhold til hinanden, mens den danske partikel markerer en implicit argumentation mellem Krage og Kafka om hvad Kafka skal foretage sig. At samtalepartnerne har et tæt og venskabeligt forhold til hinanden, bliver i oversættelsen snarere udtrykt gennem tiltaleformen. Partiklerne har forskellige funktioner, og den danske partikel er ikke en oversættelse af den japanske.

I et andet eksempel taler Nakata, romanens anden hovedperson, og hans rejsekammerat Hoshino sammen på en restaurant på vej til øen Shikoku:

(5) Nakata: "Ja, Nakata er mæt. Hvad med Dem, hr. Hoshino?"

Hoshino: "Jeg er også mæt. ..." (...)

Nakata: "Ja tak, så vil en gå ud på lokummet."

Hoshino: ’Hej, ikke så højt, at alle kan høre det. Der er stadig nogen, der spiser.” (...)

Nakata: "Er det i orden, at Nakata også børster tænder?"

Hoshino: "Ja, børst du bare tænder. Vi har stadig god tid, så gør endelig, hvad du nu skal. Men tror du ikke, du skulle lade paraplyen ligge her? Du skal jo bare på toilettet.” (...)

Nakata: "Hr. Hoshino, Nakata har penge, så en kan vel få lov til at give morgenmaden." (...)

Hoshino: "Nej, den smule giver jeg gerne. Jeg skylder min bedstefar en formue fra dengang, jeg var ung og tosset." (...)

Nakata: "Mange tusind tak for mad. Det smagte dejligt."

Hoshino: "Det var bare lidt grillet makrel og en omelet på en ydmyg beverding. Du behøver ikke at bukke og skrabe på den måde." (Holm 2007: 206-207)

Det interessante ved (5) er, at partiklerne i den japanske original kun optræder i Hoshinos ytringer og ikke i Nakatas ytringer: ni partikler i Hoshinos ytringer og ingen i Nakatas. Og den skæve fordeling af partiklerne mellem Nakata og Hoshino er ikke noget særligt ved (5), denne skævhed findes næsten altid, når de to taler sammen, og den spiller en stor rolle i karakteriseringen af Nakata og Hoshino. Nakata er psykisk handikappet på grund af en ulykke fra sin barndom, så han bruger altid et meget distanceret sprog. Det vil sige, at Nakata bruger sit distancerede japansk, uanset hvor tæt et forhold han har til sin samtalepartner, også i samtalerne med hans rejsekammerat Hoshino. Derimod bruger Hoshino partikler i næsten hver ytring, og det kan man afkode som et tegn på hans engagement $\mathrm{i}$ Nakata og i samtalerne (sml. Ogi 2017: 72). Hoshinos måde at tale på med brug af flere partikler spiller også en rolle for at fortælle læseren om Hoshinos udadvendte og omgængelige karakter. På denne måde kan partiklerne i japansk bruges til beskrivelsen af en karakters personlighed.

Denne funktion ser de danske dialogiske partikler imidlertid ikke ud til have. Faktisk udtrykkes det særlige forhold mellem Nakata og Hoshino på dansk igen i stedet for med tiltaleformerne, her de asymmetriske tiltaleformer "De" eller "hr. Hoshino" i Nakatas og "du" i Hoshinos ytringer.

Et andet eksempel er fra en dialog mellem Nakata og Johnnie Walker: 
(6) Nakata: "Tror De, at Nakata kan klare det?"

Johnnie Walker:"Jeg beder ikke folk om noget, de ikke kan. Det vil jo bare være spild af tid. Synes du ikke?" (Holm 2007: 127)

I originalen bruges $n e$, hvor Holms oversættelse indeholder jo:

(7) jikan no muda to yū mono dakara ne. tid GEN spild CIT sige ting fordi PART

(7') Det vil jo bare være spild af tid.

I originalen (7) appellerer ne til lytterens enighed med påstanden. I grunden er den efterfølgende sætning

(8) sō omowa-nai kai?

sådan tænke-NEG SPØR

som Holm oversætter med "Synes du ikke?", bare en udfoldelse af denne appel. Derimod signalerer jo i det danske "Det vil jo bare være spild af tid", at samtykket allerede er forudsat af Johnny Walker. Igen er jo ikke en oversættelse af $n e$ : Mens den inkluderende partikel $n e$ inviterer til samtykke, forudsætter $j o$ allerede, at der ikke kommer indsigelse.

I næste eksempel bruges $n u$ i oversættelsen. Eksemplet er fra en scene, hvor Kafka ringer til sin veninde Sakura for at fortælle, at politiet efterlyser ham. Kafka havde lånt Sakuras mobiltelefon og mener nu, at politiet har fået fat i Sakuras mobiltelefonnummer, hvilket de kan bruge til at få fat i ham. Sakura svarer derefter:

(9) demo kocchino bangō no koto na-ra shimpai ira-nai yo.

men mit nummer GEN sag KOP-KOND bekymring behøve-NEG PART

(9') Det skal du nu ikke bekymre dig over. (Holm 2007: 271)

- hun bruger nemlig taletidskort, og hendes nummer kan ikke spores.

I originalen (9) signalerer yo, at den talende (Sakura) understreger, at Kafka skal høre godt efter, når hun fortæller ham noget (nemlig at der ikke er grund til bekymring). $N u$ i oversættelsen kan forstås således, at Sakura fremsætter et nyt synspunkt, der ikke er fremsat før i konteksten, og som modsiger modsynspunktet ("Politiet kan få fat i Sakuras nummer") (Hansen \& Heltoft 2011: 1053 ff.). ${ }^{15}$

\footnotetext{
${ }^{15}$ Ogi (2017: 27-30) afviser en analyse af yo som en partikel, der markerer, at den talende mener, at det propositionelle indhold ikke er den information, den modtagende i forvejen har ("information-state-based account"), dvs. en analyse, der svarer til Hansen og Heltofts (2011) analyse af $n u$. Men det understreger bare forskellen mellem de japanske og danske partikler.
} 
Følgende eksempel indeholder den danske partikel da. Eksemplet er fra en scene i kapitel 36, hvor Hoshino taler i telefonen med Oberst Sanders:

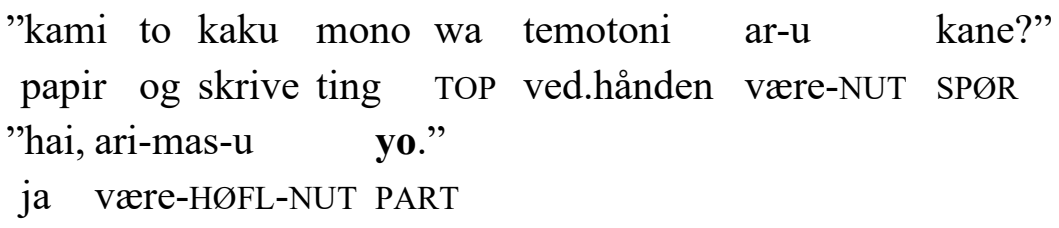

(10') Oberst Sanders: "Har du noget at skrive på?"

Hoshino: "Ja, det har jeg da." (Holm 2007: 333)

I svaret anvendes yo. På denne måde signalerer taleren, Hoshino, et underforstået "jeg er klar, værsgo at starte med at sige, hvad du gerne vil." Han er klar til at skrive det ned, som den anden part nu gerne vil sige. I oversættelsen ( $\left.10^{\prime}\right)$ bruges $d a$. I (10') må det modsynspunkt, den talende (Hoshino) forholder sig til, være, at det er uklart for Oberst Sanders, om Hoshino har noget at skrive på, og den talende (Hoshino) modsiger dette modsynspunkt og fremsætter sit eget synspunkt, "det er klart, at jeg har noget at skrive på." Dette synspunkt ser ud til at fungere både afvisende "Selvfølgelig har jeg det. Hvorfor spørger du om det?" og imødekommende "Ja, det har jeg. Hvad skal du bruge det til?". Den første analyse (afvisning) svarer til Heinemanns analyse (2009: 180), som påpeger, at $d a$ kan bruges i et svar på et spørgsmål som opfattes som upassende, da den svarende mener, at den spørgende i forvejen har den information, han eller hun har spurgt efter. Den anden analyse (imødekommelse) støttes af Hansen og Heltofts bemærkning om en mulig fatisk funktion af $d a$ : " $d a$ kan også bruges til at imødegå ikke formulerede, men potentielle modsynspunkter [...]. I denne funktion bliver adverbiet fatisk - og mere præcist - konfliktdæmpende" (2011: 1057).

Når vi fortolker $d a$ i (10') med Hansen og Heltofts "imødekommende" betydning, så ligger yos funktion i (10) og das funktion i (10') meget tæt på hinanden. Dog går det igen for vidt at konkludere, at $d a$ er en oversættelse af yo, fordi konteksten omkring (10) og (10'), som vi har beskrevet, spiller en stor rolle for at identificere yo og das funktion.

Til sidst vil vi se på brugen af partikler i oversættelse af breve. Umiddelbart vil vi ikke opfatte et brev som dialog, men et brev har en modtager og kan opfattes som et eksempel på det, som Ehlich (2007) kalder for 'zerdehnte Sprechsituation', en 'udtrukket talesituation': På grund af det skriftlige medium kan afsender og modtager være forskellige steder på forskellige tidspunkter, talesituationen er 'trukket eller strakt ud'. For de danske dialogiske partikler skaber det ikke nogen afgørende ny situation, da tilstedeværelsen af flere stemmer ikke er afhængig af tilstedeværelsen af afsender og modtager på samme sted på samme tid. Det forholder sig anderledes med de japanske interaktive partikler, som normalt beskrives som bundet til intim ansigt-til-ansigt-kommunikation. Det er dog uklart, hvilket aspekt ved denne form for kommunikation, der er afgørende her. Det ser ikke ud til at være mediet, da partiklerne kan optræde i breve, som vi straks vil se, men under hvilke betingelser?

I kapitel 11 læser vi en lille note - altså en slags brev - som Sakura har efterladt til Kafka. I dansk oversættelse: 
(11) "Jeg har set nyhederne i fjernsynet klokken syv og læst avisen fra ende til anden, men der har ikke været et eneste blodigt overfald her i nærheden, så blodet på dit tøj betyder sikkert ikke noget. Heldigvis. Der er ikke noget særligt i køleskabet, men spis, hvad du har lyst til, og lad, som om du er hjemme. Hvis ikke du har andre planer, er du velkommen til at bo hos mig et stykke tid. Hvis du går ud, så vær sød at lægge nøglen under måtten.” (Holm 2007: 93)

I den japanske original er der tre sætninger med interaktive partikler. Sætningerne, som oversættes med "blodet på dit tøj betyder sikkert ikke noget" og "Hvis ikke du har andre planer, er du velkommen til at bo hos mig et stykke tid", afsluttes med yo, og så har vi

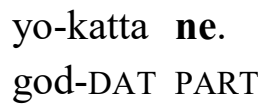

(12') Heldigvis. (Holm 2007: 93)

Kapitel 12 i Kafka på Stranden består af et langt brev fra en forhenværende folkeskolelærerinde til en professor. I dette lange brev optræder der fire gange $j o$ i den danske oversættelse, uden at det svarer til interaktive partikler i originalen:

(13) (...) og der var jo heller ingen omkomne. (...) Der skete jo så meget forfærdeligt under krigen, (...), men jeg var jo heller ikke mig selv. (...) Jeg ved jo ikke, hvad der skete med ham efter hændelsen. (Holm 2007: 97-102)

Men åbenbart er det ikke det skriftlige medium, der udelukker partiklernes optræden i den japanske original, og heller ikke genren 'brev', men forholdet mellem afsender og modtager: Professoren har meget højere social status end afsenderen, og det fremgår af brevet, at afsenderen kun har set professoren et par gange før, så professoren kan nok ikke huske, hvem hun er. I modsætning til dette kender Sakura (afsenderen i (11)) Kafka godt og betragter ham som sin lillebror, hvilket spejler sig i hendes brug af interaktive partikler. I den danske oversættelse er jo til gengæld på sin plads i begge tilfælde, da afsenderen ikke forholder sig til modtageren, men til mulige modsynspunkter som modtageren godt kunne indtage, men formodes faktisk ikke at indtage.

Her ser vi igen forskellen: Det er væsentligt for de japanske interaktive partikler, at afsenderen mener at have et intimt forhold til modtageren eller prøver at etablere det, mens de danske dialogiske partikler markerer, at afsenderen forholder sig til et muligt afvigende synspunkt, som modtageren muligvis kunne artikulere.

\subsection{EKSEMPLER UDEN FOR DIALOG}

Før vi gennemgår eksempler uden for dialog, må vi lige påpege, at der findes meget få undersøgelser af de japanske interaktive partiklers funktioner uden for dialog. Imidlertid fremgår det af Miyazaki et al. (2002) og Moriyama (1997), at partiklernes funktioner uden for dialog er noget forskelligt fra dem i dialog. Det er nærmest en følge af, at der i tale uden modtager eller i tankegengivelse ikke findes en anden person, som taleren behøver at forholde sig til. I begge tilfælde er det taleren selv, der fungerer 
som tiltalte. For de danske dialogiske partikler spiller modsynspunkter en rolle, men de kan bortset fra modtagerens eksplicit fremsatte modsynspunkter også være bare forestillede og tilhøre taleren, modtageren (som mangler uden for dialog) eller en tredje person.

I Murakamis roman finder vi $n a$ især ved gengivelse af tanker. $N a$ udtrykker ellers i dialog ud over en opfordring til modtageren til at være enig også tæt venskab mellem afsender og modtager ("cameraderie", Ogi 2017: 117f.). Derimod signalerer $n a$ uden for dialog ifølge Miyazaki et al. (2002: 28), at den talende (tænkende) genfremsætter sine følelser eller meninger; det propositionelle indhold er tænkt af den talende (tænkende) på et tidligere tidspunkt end ytringstidspunkt, og på ytringstidspunktet bekræfter den talende (tænkende) igen, at han eller hun fastholder det sagte eller tænkte.

Først vil vi se på de eksempler, hvor Holms oversættelse ikke indeholder partikler, hvor originalen har $n a$.

(14) kore wa hajimete taiken-suru koto janai na, to boku wa omo-u. det.her TOP førstegang oplevelse-gøre ting KOP.NEG PART CIT jeg TOP tænke-NUT

(14') Det er ikke første gang, jeg oplever det her, tænker jeg. (Holm 2007: 69)

$N a$ optræder også i en ytring, som den talende retter til sig selv:

$$
\begin{array}{lll}
\text { "mait-ta } & \text { na" to hoshino-san wa it-ta. } \\
\text { være.i.vildrede-DAT } & \text { PART CIT Hoshino-HøFL TOP sige-DAT }
\end{array}
$$

(15') 'Du godeste!” udbrød Hoshino. (Holm 2007: 206)

Der er intet i oversættelsen, der svarer til na. I (14') kan vi ikke gennemskue, hvordan nas funktion er gengivet, mens vi i (15') muligvis kan konstatere, at nas funktion er inkluderet i det emotive udtryk. Også af disse eksempler fremgår det, at partiklerne i originalen ikke er oversat med de danske dialogiske partikler.

I modsætning til eksempler som disse, hvor der bruges japanske partikler i originalen, men ikke nogen danske partikler i oversættelsen, er der også eksempler, hvor dialogiske partikler godt kan optræde, selv om der ikke findes en interaktiv partikel i originalen, fx når jeg-fortælleren gengiver sine egne tanker:

kanojo wa hyottoshitara
hun TOP muligvis
to jeg omo-u.

(16') Hvem ved, hun kunne jo godt være min storesøster, tænker jeg. (Holm 2007: 60) 
Her afviser Kafka modsynspunktet, at det kan udelukkes, at Sakura er hans storesøster. Men det viser bare, at danske dialogiske partikler og japanske interaktive partikler udløses af helt forskellige elementer i en interaktions- eller fortællesituation.

\subsection{EKSEMPLER I FORTÆLLERTEKST}

I Kafka på stranden optræder hovedpersonen Kafka som jeg-fortæller i hvert andet kapitel. En jegfortælling kan opfattes som en slags tale (og dermed snarere en form for monolog), som i disse eksempler:

(17) Jeg tager mælken ud af køleskabet, (...). Jeg ved jo endnu ikke, hvad der er sket i de fire timer, jeg ikke var ved bevidsthed. (...) Jeg har jo betalt forud, så det skulle næppe volde problemer. (...) Jeg kan jo ikke i al evighed lade være med at se på det sorte undertøj, hun har hængt til tørre på badekarret, (...) (Holm 2007: 93)

(18) Jeg lukker bogen, lægger den i skødet og tænker over mit eget ansvar. (...) men jeg kan da ikke tage ansvaret for noget, jeg ikke husker, insisterer jeg. (...) (Holm 2007: 132)

Også her kan dialogiske partikler optræde i en oversættelse af en sætning, der ikke indeholder interaktive partikler. På dansk indgår fortælleren i en forestillet dialog med læseren, men på japansk engagerer han sig ikke med læseren, som forbliver abstrakt og socialt ubestemmeligt.

Vi vil i det følgende især se på kapitlerne med en traditionel tredjepersonsfortæller. I disse kapitler finder vi - i modsætning til de eventyr, vi diskuterede i Haberland \& Obe (2018) - ingen brug af interaktive partikler overhovedet $\mathrm{i}$ den japanske original. Til gengæld finder vi brug af dialogiske partikler i oversættelsen.

(19) Nu blev Nakata jo ikke konstant bedt om at finde katte, så han fik ikke den store månedsindtægt ud af det. (Holm 2007: 118)

(20) Det var da hændt, at nogen kom fordi, mens Nakata stod på gaden i ivrig samtale med en kat, men det lod ikke til at gøre særligt indtryk på dem. Man ser jo tit gamle mennesker stå på gaden og tale med dyr, som om de var mennesker. (Holm 2007: 119)

(21) Nakata var stadig lidt fortumlet, men det lykkedes ham da at gå. (Holm 2007: 336)

(22) Det føltes lidt mærkeligt at lægge sig til at sove midt på dagen på opfordring fra en kat, men han fik da sovet en times tid. (Holm 2007: 443)

Det er af en vis interesse, at de dialogiske partikler, som er brugt i fortællertekst i oversættelsen, oftest er jo eller $d a$. En række andre dialogiske partikler som nu, ellers eller altså optræder i dialog i oversættelsen, men ikke i fortællertekst. Vores korpus er alt for lille til at sige noget afgørende, men det kunne være, at nogle danske dialogiske partikler alligevel forudsætter en faktisk samtale, mens nogle andre dialogiske partikler (muligvis jo og $d a$ ) også frit kan optræde, når dialogen kun er implicit. 


\section{KONKLUSION}

Analysen af forholdet mellem dialogiske partikler og interaktive partikler i en litterær oversættelse fra japansk til dansk har som ventet vist, at det ikke er den enkelte partikel oversætteren oversætter. Snarere forsøger oversætteren at gengive hele den ikke-propositionelle del af ytringens mening i oversættelsen. Hvor de danske dialogiske partikler udtrykker de forskellige stemmer i en virkelig eller forestillet dialog, understreger de japanske interaktive partikler samtalepartnernes indbyrdes forhold. Da flerstemmethed og implicit dialog på den ene side og de sociale relationer mellem samtalepartneren på den anden side ikke er helt adskilte, kan det nogle gange virke som om de danske partikler fanger et aspekt ved de japanske partiklers funktion. Men selv om de danske og japanske partikler tangerer hinanden i deres funktion, så er deres funktioner ikke præcist parallelle. På japansk kan man ikke ytre sig uden at tænke samtalepartneren med, men man fokuserer ikke nødvendigvis på samtalepartnerens (eller uden for dialog sine egne) modstridende eller overensstemmende synspunkter, som man gør på dansk.

Det var Torben Andersen, der i 1982 for første gang påpegede, at de danske 'modalpartikler' hører hjemme i dialog (Andersen 1982). Umiddelbart kunne det pege på en lighed med de japanske interaktive partikler, da de i endnu højere grad optræder i dialog. Men analysen i Hansen og Heltoft (2011) har gjort det tydeligt, at 'dialog' snarere skal forstås som en situation, hvor der kan opstå flere synspunkter, de talende kan forholde sig til; de danske partikler relaterer sig til udtrykte, ikke-udtrykte og mulige modsynspunkter og kræver ikke tilstedeværelse af de personer, der støtter dem; de tåler Ehlichs 'zerdehnte Sprechsituation'. Japanske interaktive partikler kræver derimod en konkret dialogpartner. Som vi har vist i Haberland \& Obe (2018), er partnerens tilstedeværelse en betingelse, der der dog kan ophæves fx i fortællerteksten i børnebøger (som i H. C. Andersen-oversættelser), fordi der kun forudsættes en socialt tydeligt defineret lytter ( $\mathrm{fx}$ et barn), ikke en faktisk tilstedeværende. At kravet om tilstedeværelse kan slækkes når modtageren er socialt defineret, forklarer sandsynligvis også at de japanske dialogiske partikler kan optræde uden for dialog og i sidste ende også i ikke-formelle breve som i eksempel (11).

Det er fuldstændigt korrekt at påpege, at "Japansk har skam partikler" (Refsing 2011), på samme måde som dansk og de andre germanske partikelsprog. Men skinnet bedrager: Det som på overfladen ligner, viser sig at være meget forskellig, når man inddrager en funktionsanalyse.

Rie Obe

Institut for Sprog og Kultur (Dansk)

Osaka Universitet

rieobe@lang.osaka-u.ac.jp

Hartmut Haberland

Institut for Kommunikation og Humanistisk Videnskab

Roskilde Universitet

hartmut@ruc.dk 
A number of 'small words' in modern Germanic Verb second languages share features with sentence final particles in Asian languages. However, it is not clear how far the parallel goes. We investigate Danish dialogical particles and Japanese interactive particles by comparing excerpts from a text by Haruki Murakami and its Danish translation. Although these particles within the typological framework of their respective languages share surprisingly many features, they rarely function as direct translations of each other. Danish dialogical particles refer to a dialogue (which may be implicit), i.e. they presuppose the presence of more than one voice (some would call this polyphony) while Japanese interactive particles organize the mutual involvement of interactants.

Keywords: dialogical particles, interactive particles, Danish, Japanese

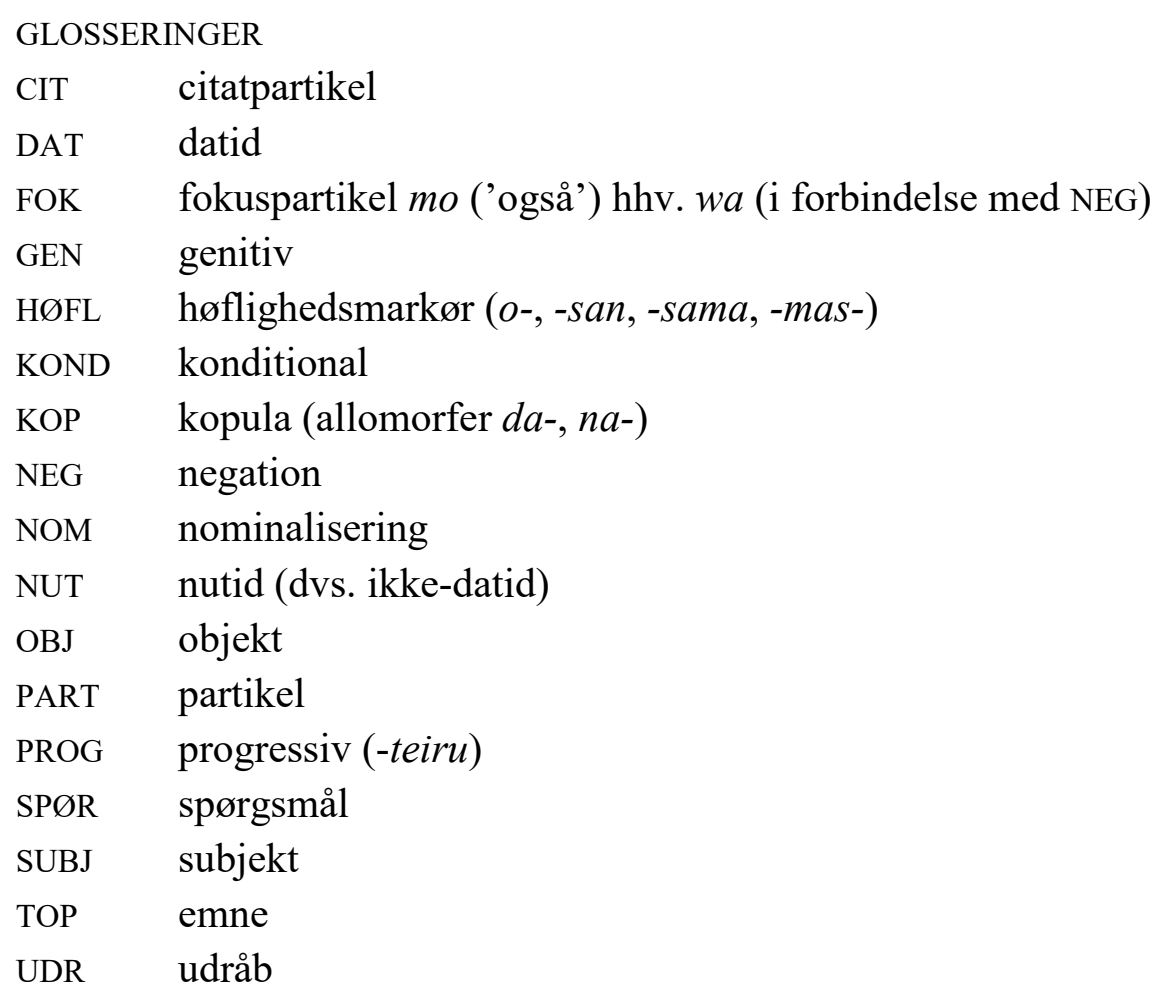

\section{LITTERATURLISTE}

Aijmer, K., A. Foolen \& A.-M. Simon-Vandenbergen. 2006. Pragmatic markers in translation: a methodological proposal. K. Fischer (red.), Approaches to Discourse Particles, 101-114. Amsterdam: Elsevier.

Andersen, T. 1982. Modalpartikler og deres funktion i dansk. Danske Studier 1982. 86-95.

Arndt, W. 1960. "Modal Particles" in Russian and German. Word 16(3). 323-336.

Baunebjerg, G. \& M. Wesemann. 1983. Partikelwörterbuch Deutsch-Dänisch, Dänisch-Deutsch. Ein Arbeitsbericht. H. Weydt (red.), Partikeln und Interaktion, 119-129. Tübingen: Niemeyer.

Bloch, B. 1946. Studies in Colloquial Japanese II. Syntax. Language 22(3). 200-248.

Cooke, J. R. 1989. Thai sentence particles: forms, meanings, and formal-semantic variations. Papers in Southeast Asian linguistics No. 12, Thai sentence particles and other topics, 1-90. Canberra: Pacific Linguistics, The Australian National University. 
Coulmas, F. 1985. Direct and indirect speech: General problems and problems of Japanese. Journal of Pragmatics 9(1). 41-63.

Ehlich, K. 2007. Zum Textbegriff. K. Ehlich, red. Sprache und sprachliches Handeln, Band 3: Diskurs - Narration - Text - Schrift. Berlin: de Gruyter, 531-550 (oprindeligt 1984)

Gray, B. 1977. From discourse to dialog. Journal of Pragmatics 1(3). 283-297.

Ha, K. \& M. Grice. 2017. Tone and intonation in discourse management - How do speakers of Standard Vietnamese initiate a repair? Journal of Pragmatics 107. 60-83,

Haberland, H. \& R. Obe. 2018. Dialogiske partikler i oversættelse. En sammenligning af danske dialogiske partikler og japanske interaktive partikler. IDUN. Journal of Nordic Studies (Osaka) 23. 75-91

Hansen, E. \& L. Heltoft. 2011. Grammatik over det danske sprog, bind 1-3. København: Det Danske Sprog- og Litteraturselskab.

Hayano, K. 2011. Claiming epistemic primacy: yo-marked assessments in Japanese. T. Stivers, L. Mondada og J. Steensig (red.), The morality of knowledge in conversation. 58-81. Cambridge: Cambridge University Press.

Heinemann, T. 2009. Two answers to inapposite inquiries. J. Sidnell (red.), Conversation analysis: Comparative perspectives. 159-186. Cambridge: Cambridge University Press.

Lewin, B. 1959. Abriß der japanischen Grammatik. Wiesbaden: Harassowitz.

Luke, K.K. 1990. Utterance particles in Cantonese conversation. Amsterdam: John Benjamins.

Miyazaki, K., T. Adachi, H. Noda \& S. Takanashi. 2002.モダリティ[Modality]. Tokyo: Kuroshio Shuppan.

Moriyama, T. 1997.「独り言」をめぐって - 思考の言語と伝達の言語 - [Omkring monolog - sprog til at tænke med og sprog til at kommunikere med]. Y. Kawabata \& Y. Nitta (red.),『日本語文法 体系と方法』[Japansk grammatik - system og metode], 173-188. Tokyo: Hitsuji Shobo.

Obe, R. \& H. Haberland 2018. Anmeldelse af N. Ogi 2017, Involvement and attitude in Japanese Discourse: Interactive markers. Nordic Journal of Linguistics 41(1). 117-128.

Ogi, N. 2017. Involvement and attitude in Japanese discourse. Interactive markers. Amsterdam: John Benjamins.

Pak, M.D. 2008. Types of clauses and sentence end particles in Korean. Korean Linguistics 14. 113156.

Refsing, K. 2011. Japansk har skam partikler. Læserbrev i Dagbladet Information, 17. maj 2011, s. 19.

Schubiger, M. 1965. English intonation and German modal particles. Phonetica 12. 65-84.

Simpson, A. 2014. Sentence-final particles. C.-T.J. Huang, Y.-H.A. Li \& A. Simpson (red.), The handbook of Chinese linguistics, 156-179. Hoboken, NJ: Wiley-Blackwell.

Slobin, D. I. 1996. Two ways to travel: Verbs of motion in English and Spanish. M. Shibatani \& S. Thompson (red.), Grammatical Constructions, 195-219. Oxford: Clarendon Press.

Wienold, G. 2004. Translation between distant languages: The case of German and Japanese. H. Kittel et al. (red.), Übersetzung Translation Traduction: Ein internationales Handbuch zur Übersetzungsforschung, 415-430. Berlin: de Gruyter. 
Andersen, Hans Christian. 1943. H. C. Andersens Eventyr og Historier i 5 bind, red. Hans Brix og Anker Jensen. København: Gyldendal

Andersen, Hans Christian. 1963. H. C. Andersens Eventyr, fortalte for Børn 1835-42, red. Erik Dal og Erling Nielsen. København: Det danske Sprog- og Litteraturselskab. (=Dal)

Andersen, Hans Christian. 1974. H. C. Andersens eventyr i udvalg. København: Notabene.

Fukui Nobuko (oversætter, 福井信子). 1988. Kejserens nye kloeder. Tokyo: Daigaku Shorin.

Murakami Haruki. 2009a (2005).『海辺の力フ力』(Umibe no Kafuka)（上） Bind 1. Tokyo:

Shinchosha.（=村上·上）

Murakami Haruki. 2009b (2005).『海辺の力フカ』(Umibe no Kafuka)（下） Bind 2. Tokyo:

Shinchosha.（=村上・下）

Murakami Haruki (oversat af Mette Holm). 2007. Kafka på stranden. Århus: Forlaget Klim. $(=$ Holm $)$

Ōhata Suekichi (oversætter, 大畑末吉). 2016 (1984). Kōtei no atarashii kimono [Kejserens nye Klæder], i: アンデルセン傑作童話集（一）[H.C. Andersens Eventyr, bind 1.]. Tokyo: Iwanami Shoten.

Ōkubo Yū (oversætter, 大久保ゆう) 1999. Hadaka no ōsama [Kejserens nye Klæder]. http://www.alz.jp/221b/transbox.html, https://www.aozora.gr.jp/cards/000019/card46319.html (tilgået 21. maj 2018) 
Appendiks (kun on-line)

(1')「そうか、わしもしたくができたぞ。」Ōhata 2016: 163

(1”)「わかった、わしだったら用意ができているぞ。」Fukui 1988: 125

(2')「王さま、はだかだよ。」Ōkubo 1999

(3)「たぶんね」（...）「ねえ、君はもっと世間ってものを知らなくちやいけないよ。（...）だいたい君はま だ義務教育だって終えていないんだぜ（...）」（...)「まあいいや」（...)「まだなんにも始まっても いないうちから、暗いことばかり並べたててもしょうがないものな。君はもう心をきめたんだ。（...）」 （...）「しかしこれから先、君はずいぶんタフにならないとやっていけないぜ」「努力はしている」（...) 「たしかに」（...）「この何年かで君はずいぶん強くなった。そのことを認めてないってわけじゃないんだ よ。」（...）「（...）君がこれまで見たこともないようなものが、世界にはいっぱいあるわけさ。今の 君には想像もできないようなものがね。」（...）「でもなにがあっても、僕はここから出て行かなくちや ならないんだ。それは動かしようのないことだよ。」「そうかもしれない」（...）「（...）またまた君の決 意に水を差すようだけど、どれほど遠くまで行ったところで、君がうまくここから逃げだせるかどうか、そ れはわかったものじやないぜ。距離みたいなものにはあまり期待しないほうがいいような気がするね。」 （村上·上 7-9）

(4)「ねえ、君はもつと世間ってものを知らなくちやいけないよ。」（村上・上 7）

(5)「はい。ナカ夕はおなかいっぱいになりました。ホシノさんはいかがでしよう？」「俺も腹いっぱいだよ。 (...)」（...)「はい。ありがとうございます。それではナカ夕はウンコをして参ります」「あのね、そんな 大きな声で、みんなに聞こえるように復唱することねえんだよ。ほかの人はまだメシを食ってるんだか らさ」（...）「ついでに歯も磨いてきてかまいませんでしょうか」「いいよ。歯も磨いてきな。まだ時間は あるから、好きなことすりやいい。でもさ、ナカタさん、傘くらいは置いていった方がいいんじやねえかい。 ちょつと便所にいくだけなんだからさ」（...）「ホシノさん、ナカ夕はちやんとお金を持っておりますので、 朝ご飯のぶんくらいはナカタが払います」（...）「いいんだよ、これぐらいのもの。俺な、うちのじいちゃ んにはずいぶん借りがあるんだ。昔、グレてたころ」（...）「ありがとうございます。それではご馳走に なります」「たかがしけた食堂のアジと卵焼きだ。そんなぺこぺこ礼を言われるほどのことじやねえよ」 （村上·上 443-445） 
(6)「それはナカ夕にできますことでありましょうか？」ー「私はできないことは人には求めない。だってできな いことを求めても、時間の無駄というものだからね。そう思わないかい？」（村上·上 268）

(7)「時間の無駄というものだからね。」（村上・上 268）

(8)「そう思わないかい?」（村上·上 268）

(9)「でもこっちの番号のことなら心配いらないよ。」（村上·下 104）

(10)「紙と書くものは手元にあるかね?」ー「はい、ありますよ」（村上·下 241）

(11)「テレビの 7 時のニュースも全部見たし、新聞も隅まで読んだ。でもこのあたりでは、血が流されたよう な事件はひとつも起こっていない。あの血はきっとなんでもなかったんだよ。よかったね。冷蔵庫には たいしたものは入ってないけど、好きに食べていい。あるものはなんでも使っていい。行くところがなけ れば、うちにしばらくいていいよ。出るときには鍵はマットの下に入れておいて」（村上・上 193）

（12）「よかったね。」（村上・上 193）

(13)（...）誰が死んだというわけでもありません。（...) なにしろ戦争中には耳を覆いたくなるようなむ ごいことが多々起こりましたし、（...) でもそこにいるのは私ではありませんでした。（...）中田君が あの事件後どうなったのか、私にもわかりません。（村上・上 202-212）

(14)これは初めて体験することじやないな、と僕は思う。（村上·上 141）

(15)「参ったな」と星野さんは言った。（村上・上 442）

（16）彼女はひよつとしたら僕のお姉さんなのかもしれないと思う。（村上·上 122）

(17) 僕は冷蔵庫から牛乳を出し、（...) 失われた 4 時間のあいだになにがあったのか、僕にはまだわか ってはいないのだ。（...）部屋代は前払いしてあるので問題はないはずだ。（...) 洗面所に干して ある彼女の小さな黒い下着から目を背けつづけるわけにはいかない。（...）（村上·上 193-196）

（18）僕は本を閉じ、膝の上に置くっそして自分の責任について考える。（...）記憶にないことには責任 を持てないんだ、と僕は主張する。（...）（村上·上 278）

(19) いつもいつも猫探しの依頼があるというわけではないから、一ヶ月を通してみればたいした収入には ならなかったけれど、（村上・上 247）

(20) 彼が道ばたでどこかの猫と熱心に会話をしているときに、人がたまたまそばを通りかかることはあった けれど、それを見ても、誰もべつに気にはとめなかった。老人が動物に向かって、人に対するように語 りかけているのは、とくに珍しい情景ではない。（村上·上 248）

(21) ナカタさんはまだ足もとが少しふらついていたが、なんとか歩くことはできた。（村上・下 248） 
(22) 猫の言いなりになって昼寝をするというのも奇妙なものだったが、実際に横になってみると 1 時間ば かりぐつすりと眠ることができた。（村上・下 491-492） 